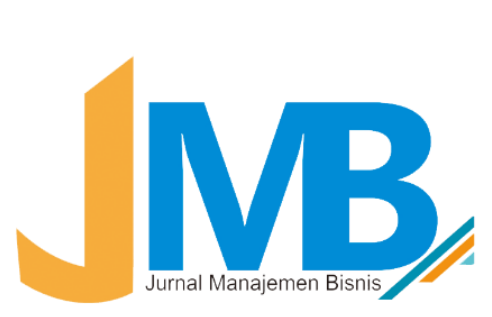

\title{
Strengthening Digital Start-Up Dynamic Capabilities in Malang City through Design Thinking and Entrepreneurship Orientation.
}

Widi Dewi Ruspitasari ${ }^{1}$, Widiya Dewi Anjaningrum ${ }^{2}$, Mega Mirasaputri Cahyanti ${ }^{3}$

Institut Teknologi dan Bisnis Asia Malang, wididewi@asia.ac.id, Indonesia ${ }^{l}$ Institut Teknologi dan Bisnis Asia Malang, widiya.dewi.a@asia.ac.id, Indonesia ${ }^{2}$ Institut Teknologi dan Bisnis Asia Malang, mega_mc@asia.ac.id,Indonesia ${ }^{3}$

Received:01-09-2020 | Revision: 20-09-2020 | Accepted:20-10-2020

To cite this document:

Ruspitasari, Widi Dewi, Widiya Dewi Anjaningrum, and Mega Mirasaputri Cahyanti (2020) " Strengthening Digital Start-Up Dynamic Capabilities in Malang City through Design Thinking and Entrepreneurship Orientation ", Manajemen Bisnis, Vol. 10 No. 02, pp.62-77, https:// doi: 10.22219/jmb.v10i2.13552

\begin{abstract}
Digital start-up is one part of the creative economy that is currently growing rapidly in Malang town. Looking at this rapidly changing environment in the era of the industrial revolution 4.0, it is important for digital start-ups to improve dynamic capabilities. The purpose of this study was to determine the effect of design thinking and entrepreneurial orientation on dynamic digital start-up capabilities. A total of 100 start-up actors have been selected as research samples. Quantitative data collected through questionnaires were analyzed using PLS analysis. The results showed that both design thinking and market orientation had a great influence on dynamic digital start-up capabilities. The strongest factor in the design thinking is the emphatize process so that the ability of start-ups to feel the environment and understand customer needs and market dynamics better than competitors. While the strongest factor in entrepreneurship is the courage to act to achieve goals so that start-ups are able to face market competition. Suggestions for further research is need to focus on two weaknesses factors, there are, the process of ideas in conducting design thinking and the lack of initiative in initiating innovative actions, because the innovation today is urgently needed to win the market competition.
\end{abstract}

Keywords: Digital Start-up; Dynamic Capabilities; Design Thinking; Entrepreneur Orientation

\section{INTRODUCTION}

The industrial world is currently entering a new era, namely the era of the Industrial Revolution 4.0 which is marked by the massive development of information technology. This revolution started with the discovery of the Internet of Things (IoT) in the 90s which was growing rapidly and had a major impact on human life and provided

\footnotetext{
${ }^{1}$ wididewi@asia.ac.id
} 
new opportunities and challenges for every country in a highly competitive global competition. To face these challenges, the Ministry of Industry of the Republic of Indonesia has designed a roadmap called Making Indonesia 4.0 (Rozaq, 2018).

This roadmap is expected to increase the competitiveness of national industries in the global arena, and can make Indonesia the top 10 world economy in 2030 with all the advantages provided by the era of the Industrial Revolution 4.0 (Rachman, 2018). One of the advantages from this era is the creation of more work and new technology-based investments, especially in the form of digital startups (Noor, 2018). Moreover, there still only 3 (three) Indonesian startups that have succeeded in becoming unicorns, namely startups that have a valuation of above US \$ 1 billion (Rp.13.5 trillion), including: Gojek, Tokopedia and Traveloka or known as GTT (Primary, 2017). This is an opportunity for the Indonesian citizen, especially the millennial generation, to become digital entrepreneurs and strive to be included in the unicorn category.

This opportunity is supported by the great potential from internet users in Indonesia which has reached 133 million people, which of course will continue to grow every year. In addition, people's purchasing power also increases in line with the increasing of per capita income of the community (Amalia, 2017) and the demographics in 2045, which is predicted to have more young people than older people (Ant, 2018). So, digital startups are a very promising business and also supported the achievement of Indonesia as The Digital Energy of Asia (Febrianti, 2018).

Digital startups are part of the creative economy sector, such as applications and games subsector. One of the cities that has great potential to become a leading creative city and has established applications and games as a leading sub-sector is Malang (Zulfikar, 2017). In fact, seeing the increasing number of animators, information technology experts and the like, the city government has planned to register creative digital developments in Malang to UNESCO (Arifin, 2016). However, a stronger reason for declaring the city of Malang as a creative digital city is the results of the sampling test by the Independent Ranking Team for Creative District / City of Indonesia (PMK3I) under the auspices of the Creative Economy Agency (Bekraf) of the Republic of Indonesia, which shows that the 3 sub-sectors of the creative industry are Malang city priorities, namely: (1) Culinary, (2) Applications and Games, and (3) films, animation and video, applications and games sub-sectors are designated as the leading creative economy sub-sectors of Malang (Choirul, 2017).

There are 2 strong reasons that make applications and games the leading creative economy (Ekraf) sub-sector of Malang, namely: (1) this sub-sector has grown and developed since 2011 with a background of basic knowledge about the information technology industry, and (2) the performance of the sub-sector. Applications and games to date include more than 2,200 actors, 6 communities, 96 entrepreneurs, 4,800 academic graduates whose annual activities cover national scale and international scale business operations. It is estimated that the number of workers absorbed is currently 2,200 people with an estimated growth of $20 \%$ per year (Jati, 2017).

The real contribution that has been given by the city government of Malang to make Malang as a leading creative digital city is by hosting the 2016 Indonesia Creative Cities Conference (ICCC) which was attended by delegations from a number of ASEAN countries (Widianto, 2016). Also formation of Malang Creative Fusion as a forum dynamic creative communities from each sub-district to meet and work together (Yusnia and Irma, 2016). In fact, currently, the mayor of Malang is also trying to increase the potential of the generation nd ECRAF - Creative Economy of the Malang 
city, where its manifested in the form of mapping and roadmaps for 3 priority ECRAF sub-sectors of Malang. The economic growth of Malang city in 2015 has reached $5.61 \%$, higher than East Java which was $5.56 \%$, even higher than the national level which was $5.18 \%$ (Poerwanto, 2017) with a controlled inflation rate. This achievement is inseparable from the contribution of the creative economy sector, especially the applications and games sub-sector or better known as the digital business (Adhi, 2018).

The potential of the city of Malang in the digital startup business world fully supports the implementation of the fourth-generation industry. However, this implementation will not be able to run effectively and be able to move all economic sectors without being followed by the formation of a healthy and sustainable ecosystem. Thus, it is important for each stakeholder to collaborate synergistically with each other to understand the market and map the characteristics of the undeserved market, namely a market that has not been well served by the use of technology, then determine a competitive strategy that is balanced by appropriate government regulations to deal with technological innovation and character of fast changing market (Noor, 2018).

The rapid changing of market and the significant growth of digital startups are also threating to the business itself. The threat is in the form of competition between similar businesses that are getting tighter, so that every business must have the capability to face any changes. Samson \& Mahmood (2014) said that dynamic capabilities are influenced by entrepreneurial orientation. Meanwhile, dynamic capabilities can also be significantly enhanced by implementing design thinking in every company problem-solving process (Llamas, 2015; Kurtmollaiev et al., 2018). This shows that the dynamic capabilities of a creative industry are strongly influenced by the entrepreneurial orientation of its creative-preneur and design thinking.

So far, research has rarely linked the three variables, namely design thinking, entrepreneurial orientation and dynamic capabilities simultaneously, and discusses the relationship between these three variables, so the objectives of this study are to: (1) determine the effect of design thinking on dynamic capabilities start. -up digital in Malang city, and (2) determine the effect of entrepreneurial orientation on dynamic digital start-up capabilities in Malang.

\section{LITERATURE REVIEW}

Dynamic capabilities according to Teece et al. (1997) is a firm's ability to integrate, build, and reconfigure internal and external competencies to cope with a rapidly changing environment. The three main dimensions of dynamic capabilities according to Maclnerney-May (2012) are sensing, learning, and reconfiguration capabilities. The research results of Chukwuemeka \& Onuoha (2018) reveal that sensing capabilities help increase competitive advantage through early detection of competition between similar companies, learning capabilities strengthen organizations that are able to identify and acquire the knowledge needed both internally and externally which ultimately leads to competitive advantage. and configuration capabilities drive a firm's competitive advantage by recognizing and converting existing knowledge into new resources.

Meanwhile, researched by Samson \& Mahmood (2014) of SMEs in developing countries, especially in Nigeria, reveals that dynamic capabilities are influenced by entrepreneurial orientation. The integration of this entrepreneurial orientation and dynamic capabilities gives the result that the potential and opportunities of small and medium enterprises to play their role as machines for poverty alleviation, job creation, 
development and industrialization are not a mirage. To realize these potentials, there must be a shift in the focus pattern, where the problem of SMEs is not only a financial problem, but more importantly a managerial problem (Ogunsiji, 2010). The use of incentive resources provided by the government or those generated by the owners must be optimized optimally. Although developing an entrepreneurial culture seems expensive, it will yield benefits for companies operating in a turbulent environment (Jantunen, 2005). Therefore, SMEs must be innovative, aggressive, proactive and take calculated risks to survive in a turbulent environment where managers must think less of funding in successful business development but better prepared to learn and develop learning abilities so that they can increase their capabilities to face competition. SME owner managers must embrace science and technical education, practice partnership and equity participation, maintain quality in production, respect payment obligations, and SME management staff should be developed.

Entrepreneurial orientation, according to Wiklund et al. in Zehir et al. (2015), referring to the strategic orientation of the company, capture certain entrepreneurial aspects of decision-making styles, methods, and practices. In other words, it is the processes, practices, and decision-making activities that lead to new entries (Fang et al. 2009). Entrepreneurship has the essence of referring to the nature, character and traits inherent in someone who has a strong will to realize innovative ideas in the real world of business and can develop them resiliently. Porter in Lechner \& Gudmundsson (2014) defines entrepreneurial orientation as a corporate benefit strategy to be able to compete more effectively in the same market place. Entrepreneurial orientation refers to processes, practices, and decision-making that lead to new directions and has three aspects of entrepreneurship, namely always being innovative, acting proactively and taking risks.

The entrepreneurial orientation of an entrepreneur can lead to an increase in dynamic capabilities in facing competition which in turn can improve business performance. A person will not experience development without using mental and physical effort to create a positive engineering for one change. An entrepreneur always tries to make innovations to improve a situation (Machfoedz, 2010). Innovation is defined as the ability to apply creativity in order to solve problems and opportunities to improve and enrich life (Suryana, 2007). Innovative refers to an entrepreneurial attitude to be involved creatively in the process of experimenting with new ideas that make it possible to produce new production methods so as to produce new products or services, both for the current market and for new markets. Meanwhile, proactive reflects the willingness of entrepreneurs to dominate competitors through a combination and aggressive and proactive movements, such as introducing new products or services on top of competition and activities to anticipate future demands to create change and shape the environment. Active and dynamic attitude are the key words.

Proactive is also shown as aggressive-competitive attitude, which refers to the company's tendency to compete fiercely and directly for all competitors to be the best. The success obtained through employees' efforts to obtain entrepreneurial opportunities is a major source of growth and innovation for the company (Michael, 2011). Daring to take risks is an attitude of courage to face challenges by exploiting or engaging in business strategies where the possible results are full of uncertainty. The main function of the importance of entrepreneurial orientation is how to involve measuring risk and taking risk optimally (Basrowi, 2011). So, an entrepreneurial orientation that is reflected 
in an attitude that full of innovation, proactivity and courage to take risks is believed to be able to boost company performance (Cantaleano et al., 2018).

Meanwhile, the old entrepreneurship researcher, Miller (1983), whose findings are still relevant today, explained that entrepreneurial orientation has three main components; proactive, innovative and risk-taking. Innovation reflects the tendency to support new ideas. novelty, experimentation, and creative processes, thus departing from established practices and technologies. Proactive refers to the attitude of anticipating and acting on future wants and needs in the market, thus creating a first mover advantage for competitors. Taking risk is associated with a willingness to commit a large amount of resources to projects where the cost of failure may be high (Wiklund et al., 2003) in (Zehir et al., 2015). There are 3 main dimensions that construct entrepreneurial orientation, according to Cantaleano et al. (2018), namely: Innovativeness, Proactive, and Risk Taking.

Meanwhile, dynamic capabilities can also be significantly enhanced by implementing design thinking in every company problem-solving process (Llamas, 2015; Kurtmollaiev et al., 2018). This type of research is a quasi-experimental case study. So, based on experience using design thinking that is associated with dynamic capabilities, it's because design thinking lacks theory-driven empirical research on its effects. Thus, the practical experience of design thinking is linked to the theoretical advancement of dynamic capabilities. In this study, researcher examined how the training team leader in design thinking can develop managerial abilities and change abilities; stimulate innovation in teams; and affect the operational ability of the team. Finally, the model was tested using a quasi-experimental field study with a control group and a time lag of 4 months. Intervention is a design training program that is presented in six business units that are geographically isolated from large multinational telecommunication companies. The findings indicate that the implementation of design thinking has a positive effect on the sensing and competing abilities of participants, which has a positive effect on the ability of transformation, team innovation output, and team operational capability. In other words, design thinking has a positive impact on dynamic capabilities.

Design thinking is a methodology that is carried out through deep understanding (insight) on the customer or user to find solutions to problems or ideas for improvement opportunities. Design thinking consists of 5 stages, namely: exploration (empathize), identification (define), ideation (ideate), visualization (prototype) and evaluation (test) (Plattner, 2010).

Design Thinking is a design methodology that provides a solution-based approach to solving problems. It is particularly useful in overcoming complex problems that are unclear or unknown, by understanding the human needs involved, by reframing the problem in a human-centered way, by creating multiple ideas in brainstorming sessions, and by adopting a hands-on approach to prototyping and testing. Understanding these five stages of Design Thinking will empower anyone to apply Design Thinking methods to solve complex problems that occur in companies, countries, and even the world.

However, in this study, design thinking will focus on the five-stage model proposed by the Hasso-Plattner Design Institute at Stanford (d.school). The five stages of Design Thinking, according to d.school, are as follows: Empathize, Define (problem), Ideate, Prototype, and Test.

Empathize, the first stage of the Design Thinking process is to empathize to get an empathic understanding of the problem that is trying to solve. This involves an 
expert consultant finding out more about the area of concern through observation, engagement and empathy with people to understand their experiences and motivations, as well as immersing oneself in the physical environment to have a deeper personal understanding of the issues involved. Empathy is essential to human-centered design processes such as Design Thinking, and empathy enables design thinkers to put aside their own assumptions about the world to gain insight into users and their needs. Depend on time constraints, a large amount of information is gathered at this stage for use during the next stage and to develop the best possible understanding of users, their needs, and the problems underlying the development of a particular product.

The literature relevant to this stage is Kirkman et al. (2014) in a conceptual article extends research on team processes and individual-level behavior to develop a multilevel framework, which dynamically shapes team altruism, builds and identifies its key dimensions. This work aims to complement existing understandings of team egoistic behavior and advance research on team processes by portraying those who are more altruistic than those who are more egotistical. Then Muller et al. (2014) also explored the role of employees as drivers for corporate philanthropy, where it is more emphatic. These findings integrate the arguments from affective event theory, intergroup emotion theory, and influence infusion theory, to develop a framework in which organizational members' collective empathy in response to the needs of unknown people contributes to executive decision making, thereby influencing the likelihood, scale, and form of philanthropy company.

What is done in the Emphatize stage is to carry out exploration, which is the observation of continued interaction with the real experience to get information about the customer or user profile. Exploration is an activity to get an in-depth understanding of the customer or user. When exploring, the explorer tries to dive into the experiences or experiences of the customer or user to empathize with one heart and one frequency. The success of the explorer to empathize with the customer or user makes the explorer able to understand his thoughts, feelings, points of view, and behavior, so that we can provide the right idea or solution. Exploration is a physical activity that is being carried out, which can be in the form of words or utterances conveyed, to answer: (1) who is the customer or user (gender, age, profession), (2) what is felt, thought and needed.

Define, during the meditation stage, all the information obtained during the Empathization stage is gathered. The results of the observations are analyzed and and synthesized to identify core problems. A problem must be defined as a problem statement in a human-centered manner.

The Define stage will help the designers on the team gather great ideas for defining features, functions and any other elements that will allow the problem to be solved, or, at the very least, allow the user to solve their own problem with the minimum level of difficulty. At the define stage, mapping the results of exploratory identification and conclusion of findings to gain insight (insight) about the customer or user needs. Identification is mapping the exploration data based on its source, then understanding the findings so that user insights can be found. The stages of identification are: (1) mapping data on an empathy map, (2) understanding the findings, (3) determining user (who), need, insight (why).

As for some literature relevant to this stage, Harvey (2014) in a theoretical paper proposes that the creative synthesis process increases the chances that each group idea is a breakthrough. Then it describes the facilitator process of creative synthesis and the implications of the dialectical model for understanding extraordinary group creativity. 
Creative synthesis provides an alternative way for groups to incorporate their cognitive, social, and environmental resources into extraordinary outputs. Previously, Baer, et al. (2012) through a conceptual article establish the strategic problem formulation by developing a theory that predicts the core part of the barriers to formulation that arise when a problem becomes complex handled by a heterogeneous team. Grant \& Berry (2011) draws on motivated information processing theory, proposing that the relationship between intrinsic motivation and creativity is enhanced by psychological processes. Perspective taking, such as that generated by prosocial motivation, encourages employees to develop useful as well as novel ideas.

Ideate, in the third stage of the Design Thinking process, designers are required to generate ideas for solutions to problems. The designer must understand the needs of the customer or user at the Empathize stage, and have analyzed and synthesized the designer's observations at the Define stage, and end up with a human-centered problem statement. With this strong background designers and team members can start thinking "out of the box" to identify new solutions to existing problems, and can start looking for alternative ways of looking at problems. There are hundreds of Idea techniques such as Brainstorm, Brainwrite, Worst Possible Idea, and SCAMPER. Brainstorming and Worst Possible Idea sessions are usually used to stimulate free thinking and expand problem space. It is important to come up with as many ideas or problem solutions as possible at the beginning of the Ideation phase. The designer should select another Ideation technique at the end of the Ideation phase to help investigate and test ideas to find the best way to solve the problem, or provide the necessary elements to avoid the problem.

Harvey \& Kou (2013) conducted an inductive qualitative process analysis of four US care policy groups that were tasked with producing creative output. The results show that evaluation does not hinder group creativity. They develop the concept of evaluation as a generative process that shapes and guides collective creativity.

Prototype, the design team will now produce a number of inexpensive, scaled down versions of the product, or special features found in the product, so that they can investigate solutions to problems generated in the previous stage. Prototypes can be shared and tested within the team itself, in other departments, or in small groups of people outside the design team. This is an experimental phase, and the aim is to identify the best possible solution to each problem identified during the first three stages. The solutions are implemented in prototypes and, one-by-one, are investigated and accepted, corrected and reviewed, or rejected on the basis of user experience. By the end of this stage, the design team will have a better idea of the constraints inherent in the product, the problem at hand, and have a better perspective or more information on how real users will behave, think, and feel when interacting with the final product. .

Test, the designer or evaluator rigorously tests the complete product using the best solutions identified during the prototyping phase. This is the final stage of a 5-stage model, but in an iterative process, the results generated during the testing phase are often used to redefine one or more problems and inform user understanding, user conditions, how people think, behave, and feel, and empathize. Even during this phase, changes and improvements are made to get rid of problem solutions and gain a deep understanding of the product and its users.

\section{RESEARCH METHOD}

This research is a field research conducted using a quantitative approach. The number of the population of this research object is unknown because the digital start-up 
in Malang cannot be predicted because the number continues to experience growth. So that the sampling was done by accidental - snowball - purposive sampling method which is part of non-probability sampling, namely the research sampling technique by finding digital start-up entrepreneurs in Malang by chance, then given an online questionnaire using google-form and respondents. These have criteria that are considered by researchers, namely: (1) willing to be a respondent, (2) at least 1 (once) run a digital start-up or have at least 1 (one) application or 1 (game) game and (3) can provide all the information needed in research through questionnaires, (4) maximum business age 3 years. In addition, researchers also asked respondents for help in sharing the google-form research link (online questionnaire) with fellow respondents who also run a digital startup business. The number of samples taken in this study were 100 respondents. This is in accordance with Wibisono's calculations in Akdon (2013) for an unknown population. The collected data was finally analyzed using Partial Least Square (PLS) analysis in order to achieve a more in-depth analysis, namely up to the indicator level.

Table 1. Indicators and Items of Each Research Variable

\begin{tabular}{|c|c|c|}
\hline Variabel & Indikator & Item \\
\hline \multicolumn{2}{|c|}{ Design Thinking (X1) Emphatize } & Emphatize (eksplorasi) (X11) \\
\hline \multirow[t]{5}{*}{ (Plattner, 2010) } & Define & Define (Identifikasi) (X12) \\
\hline & Ideate & Ideate (Ideasi) (X13) \\
\hline & Prototype & Prototype (Visualisasi) (X14) \\
\hline & Test & Test (Evaluasi) (X15) \\
\hline & Innovativeness & Research \& developing (X21) \\
\hline \multicolumn{2}{|l|}{ Entrepreneurial } & Initiate innovative action (X22) \\
\hline Orientation (X2) & Proactivity & First to introduce a new product (X23) \\
\hline \multirow{4}{*}{$\begin{array}{l}\text { (Cantaleano et al., } \\
\text { 2018) }\end{array}$} & & Competitive position (X24) \\
\hline & Risk Taking & Chance for high risk high return (X25) \\
\hline & & Bold actions to achieve goals (X26) \\
\hline & & A bold and aggressive posture (X27) \\
\hline \multicolumn{2}{|c|}{ Dynamic Capabilities Innovative } & Ability to develop new products and or markets \\
\hline$(Y)$ & Capability & (Y1) \\
\hline \multirow[t]{3}{*}{$\begin{array}{l}\text { Mohamud \& Sarpon } \\
\text { (2016) }\end{array}$} & $\begin{array}{l}\text { Absorptive } \\
\text { Capability }\end{array}$ & $\begin{array}{l}\text { Ability to recognize new, external information, } \\
\text { assimilate it, and apply it for commercial purposes } \\
\text { (Y2) }\end{array}$ \\
\hline & $\begin{array}{l}\text { Integrative } \\
\text { Capability }\end{array}$ & $\begin{array}{l}\text { Ability to integrate every individual input / } \\
\text { suggestion / thought in the team (Y3) }\end{array}$ \\
\hline & Sensing Capability & $\begin{array}{l}\text { Ability to perceive the environment and understand } \\
\text { customer needs and market dynamics better than } \\
\text { competitors (Y1) }\end{array}$ \\
\hline
\end{tabular}




\section{RESULT AND DISCUSSION}

As many as 100 digital start-ups in the city of Malang became respondents, $73 \%$ were male, while $27 \%$ were female, $74 \%$ had an IT (Information Technology) education background, while $26 \%$ were non-IT willing to take business opportunities in digital field. As for the results of the PLS analysis, the structural model formed is presented in Figure 1. below.

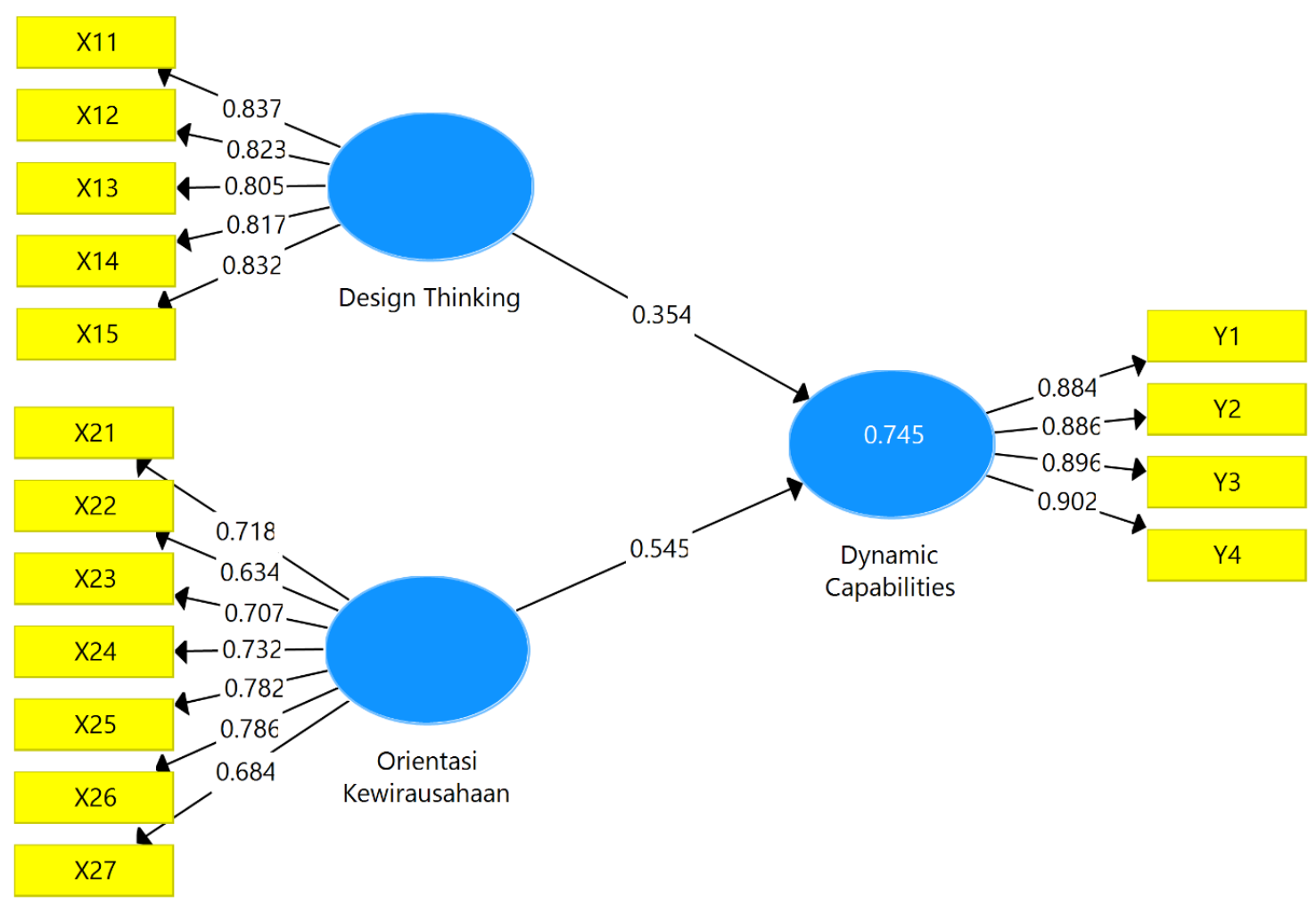

Figure 1. Structural Model

Based on Figure 1. Structural Model, for the outer model, it is known that each item that measures the latent construct is Valid, this can be seen from the loading factor value which shows the correlation between the indicator and the construct, mostly above 0.70 (Sarwono, 2014). However, this value can still be tolerated up to 0.50 and if the loading factor value is below 0.50 then the indicator must be dropped from the analysis (Ghozali, 2015), because indicators with low loading values indicate that the indicator does not work on the model measurement. Because the loading factor values of items X22 and X27 are still above 0.5, all items that reflect latent constructs are valid. When viewed from the inner model, it is known that the R-Square value is 0.745 . This means that $74.5 \%$ of the dynamic start-up digital capabilities in Malang are explained by Design Thinking and Entrepreneurial Orientation. As for the remainder, $100 \%-25.5 \%$ is explained by other exogenous constructs not considered in the study. The main structural models that are formed are as follows:

$$
Y=0,354 X_{1}+0,545 X_{2}+\varepsilon
$$

Based on this model, it is known that the path coefficient for the design thinking variable is 0.354 units in a positive direction. This means that the higher the design thinking that is applied, the higher the dynamic capabilities of digital start-up in Malang city will be. The increase in each design thinking unit will increase dynamic capabilities by 0.354 units. It is also known that the path coefficient for the entrepreneurial 
orientation variable is 0.545 units in a positive direction. This means that the higher the entrepreneurial orientation that exists in digital start-ups, the higher the dynamic capabilities the business has. The increase in each entrepreneurial orientation unit will increase dynamic capabilities by 0.545 units.

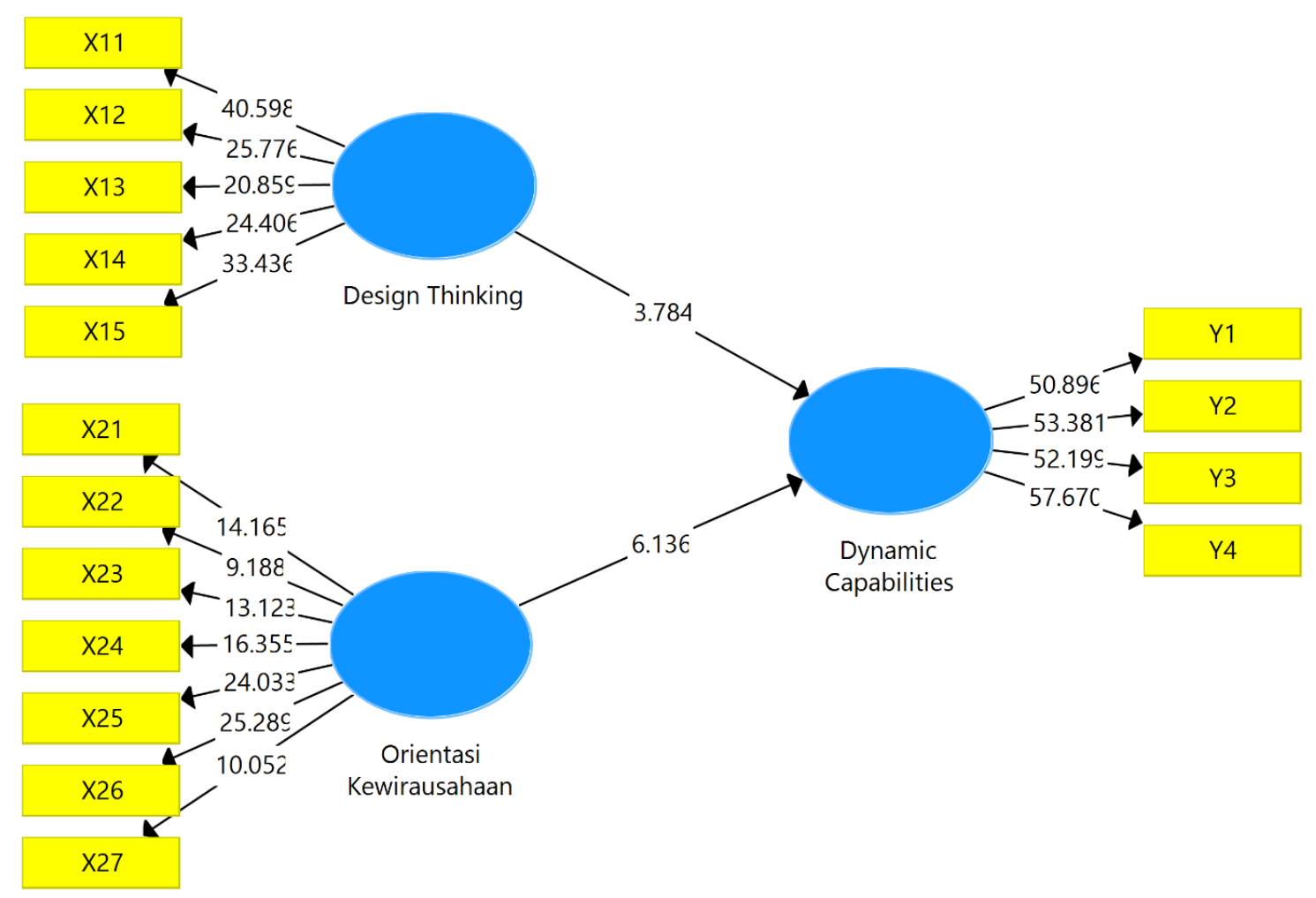

Figure 2. Output Bootstrapping

Figure 2. is the output of Bootstrapping which shows the results of the $t$ test. It is known that the t-statistics value of the effect of design thinking on dynamic capabilities is 3.784 which is greater than the normal Z-score value for $\alpha=0.05$ which is 1.96 (3.784> 1.96), meaning that the effect of design thinking on dynamic capabilities is significant. Likewise, with the t-statistics value, the effect of market orientation on dynamic capabilities is 6.136 which is greater than the normal Z-score for $\alpha=0.05$ of 1.96 (6.136> 1.96), meaning that the effect of entrepreneurial orientation on dynamic capabilities are significant. So, both design thinking and entrepreneurial orientation have a positive and significant effect on dynamic capabilities.

When examined at the level of items that reflect latent constructs, the item that most strongly (the greatest t-statistic value) that reflects design thinking is Emphatize (exploration) (X11). While the weakest (items that have the smallest $t$-statistic value) is Ideate (Ideation) (X13). The item that most strongly reflects entrepreneurial orientation is bold action to achieve goals (X26), while the weakest item is initiating innovative action (X22). Meanwhile, the strongest dynamic capability is the ability to perceive the environment and understand customer needs and market dynamics better than competitors (Y4), and the weakest item is the ability to develop new products and / or markets (Y1).

\section{DISCUSSION}

\section{Design Thinking and Dynamic Capabilities}


The results showed that design thinking has an important role in strengthening the dynamic capabilities of digital start-up in Malang. The more precise the design thinking is, the stronger dynamic capabilities will be. The results of this study support the findings of Llamas (2015) and Kurtmollaiev et al. (2018) who revealed that dynamic capabilities can be significantly enhanced by implementing design thinking in every company problem-solving process. Design thinking plays a big role in companies, especially start-ups, which are currently facing multisectoral problems as a result of the increasingly complex business models, expansion and an increasingly large business ecosystem. The application of a design thinking framework can solve the daily problems of the company which in turn can strengthen the company's dynamic capabilities.

Design thinking is a process of creating new, innovative ideas that can solve problems. This is not limited to specific industries or areas of expertise. As the definition of Plattner (2010) which explains that design thinking is a methodology that is carried out through an in-depth understanding of the needs of the customer or user. Design thinking is very useful in terms of technology, as well as services and products. Design thinking can create new products and services for customers, thereby increasing productivity in internal operations. Broadly speaking, design thinking is a collaborative method that collects many ideas from scientific disciplines to find a solution.

The solutions obtained from the results of design thinking make start-ups have sensing capability, namely the ability to feel the environment and understand customer needs and market dynamics better than competitors (Mohamud \& Sarpong, 2016). By having empathy for consumers, company personnel will be able to position themselves as consumers and then define consumer needs, so that companies know what digital applications are currently urgently needed by the community. This is closely related to absorptive capability, namely the ability to recognize new, external information, assimilate it, and apply it to commercial purposes.

The process of emphasizing and defining in design thinking can automatically trigger integrative capability, which is the ability to integrate every input or suggestion or thought of each individual in the team. Furthermore, the ideation process is the process of finding ideas for solutions to the needs of the community which is then made a digital application prototype and tested on a strong community related to innovative capability, namely the ability to develop new products and / or markets. So the five stages of design thinking can truly be the antecedents of dynamic capabilities. So that one of the keys to the success of digital start-ups in the city of Malang to face the rapidly changing market character in the era of industrial revolution 4.0 is to do design thinking on crucial issues. The more precise the results of design thinking, the more capable digital companies are in integrating, building, and reconfiguring internal and external competencies to cope with environmental changes that are increasingly difficult to predict in this era.

The design thinking process which is the strength of digital start-up in Malang is Emphatize (exploration). As explained by Kirkman et al. (2014), this strength is obtained because start-ups have team and individual level behaviors to develop a dynamic multilevel framework that makes up team altruism. Teams or employees in digital start-ups are able to become drivers for corporate philanthropy, being more empathetic towards every event, especially towards customers or users. This is consistent with the findings of Muller et al. (2014). By having this strength, of course start-ups will find it easier to know and understand problems in society, especially 
regarding their need for digital applications. However, even though they can identify problems well, these digital start-ups have weaknesses in finding ideas for solutions to these problems. This is what makes it difficult for digital start-ups in Malang to develop rapidly and become a digital company in the unicorn category.

\section{Entrepreneurial Orientation and Dynamic Capabilities}

The results showed that the entrepreneurial orientation was able to significantly strengthen the dynamic capabilities of digital start-up in Malang. The more precise the entrepreneurial orientation of the digital start-up in Malang, the stronger the dynamic capabilities it will produce. This finding fully supports the research results of Samson \& Mahmood (2014) which revealed that dynamic capabilities are influenced by entrepreneurial orientation. These findings also support Ogunsiji's (2010) empirical explanation which reveals that the integration of entrepreneurial orientation and dynamic capabilities results that the potential and opportunities of SMEs to play the role of machines for poverty alleviation, job creation, development and industrialization are real. To realize these potentials, there must be a shift in the focus pattern, where the problem of SMEs is not only a financial problem, but more importantly a managerial problem.

Entrepreneurial orientation according to Porter's theory in Lechner \& Gudmundsson (2014), is defined as a company's benefit strategy to be able to compete more effectively in the same market place. Meanwhile, dynamic capabilities according to the theory of Teece et al. (1997) is a firm's ability to integrate, build, and reconfigure internal and external competencies to cope with a rapidly changing environment. So, if the effect of entrepreneurial orientation on dynamic capabilities in this study proves to be very strong, this is an empirical show that the accuracy of the strategy chosen by digital start-ups in Malang to compete in the market place can make these start-ups capable. harnessing internal and external competence in the face of rapid changes in this era of industrial revolution 4.0.

The accuracy of the entrepreneurial orientation chosen by the digital start-up in Malang can be seen through the innovations made, the proactive level, and the risks that they dare to face. Owned research and development competencies as well as fast startups in taking innovative actions (Cantaleano et al., 2018) make start-ups have the ability to develop new products and / or markets (Absorptive Capability) (Mohamud \& Sarpong (2016) The proactive attitude of digital start-ups, especially in introducing new products and trying to have a competitive position in the market (Cantaleano et al., 2018) can increase sensing capability and absorptive capability., dare to achieve company goals, and being aggressive can increase absorptive capability and integrative capability. So, it is very important for digital start-ups to innovate, act proactively, and dare to take risks in order to have the ability to face competition in a rapidly changing environment.

Thus, entrepreneurial orientation plays an important role in enhancing dynamic capabilities and becomes an acceptable meaning to describe dynamic capabilities. In relation to digital start-ups, entrepreneurial behavior is manifested in two ways, namely in terms of the effectiveness of actors in managing their start-ups. Second, related to start-up planning to attitudes or responses in the market. The use of strategy automatically follows the character of the digital start-up itself.

The results of this study indicate that digital start-ups in Malang have the courage to achieve their goals, but are still lacking in initiating innovative actions. Therefore, the 
ability to develop products is still lacking, although the ability to experience the environment and understand customer needs and market dynamics is still better than competitors.

\section{CONCLUSION}

Based on the results of the analysis and discussion that has been conducted, several conclusions can be drawn, including: (1) Design thinking has a major influence on the dynamic capabilities of digital start-up in Malang. The more precise the results of the design thinking process, the stronger the dynamic capabilities it has. The strongest factor in the digital start-up design thinking process is the process of emphatize (exploration) so that the start-up's ability to experience the environment and understand customer needs and market dynamics is better than competitors; (2) The entrepreneurial orientation has a big influence on the dynamic capabilities of digital start-up in Malang. The more precise the entrepreneurial orientation chosen by digital start-ups, the stronger its dynamic capabilities will be. The strongest factor that exists in digital start-ups in entrepreneurship is the courage to act to achieve goals so that start-ups are able to face market competition.

Suggestions for further research are to investigate further the factors that become the weaknesses of digital start-ups in Malang, including: (1) the ideation process in doing design thinking which is still lacking in achieving the idea of "out of the box", and (2) lack of initiative in initiating innovative actions. These two things really affect the dynamic capabilities, especially the innovative capabilities. Even though in this era of very high competition, innovation capabilities are needed so that digital products become superior and win the market. In addition, it is also important to conduct research on dynamic capabilities in the creative economy sub-sector, considering that the creative economy sector has an increasing contribution to the Indonesian economy.

\section{REFERENCES}

Adhi, Adrianus. (2018). Langkah Ekonomi Kreatif Kota Malang. Diunduh dari http://suryamalang.tribunnews.com/2018/11/07/jagongan-sutiaji-bersama-gencreative-rumuskan-tujuh-langkah-ekonomi-kreatif-kota-malang pada tanggal 2 Februari 2020.

Akdon, dan Riduwan. (2013). Rumus dan Data Dalam Analisis Statistika. Alfabeta, Bandung.

Amalia, Dina. (2017). Karakter \& Perkembangan Bisnis Startup Digital di Indonesia. Diunduh dari https://www.jurnal.id/id/blog/2017/karakter-dan-perkembanganbisnis-startup-di-indonesia pada tanggal 2 Februari 2020.

Ant. (2018). Revolusi Industri 4.0, Menperin Berharap Generasi Muda Jadi Wirausaha Digital. Diunduh dari https://economy.okezone.com/read/2018/04/21/320/1889775/revolusi-industri-40-menperin-berharap-generasi-muda-jadi-wirausaha-digital pada tanggal 5 Februari 2020.

Arifin, Zainul. (2016). Kota Malang Ajukan Diri Jadi Kota Digital Kreatif ke UNESCO. Diunduh dari https://www.liputan6.com/regional/read/2472945/kota-malangajukan-diri-jadi-kota-digital-kreatif-ke-unesco pada tanggal 3 Februari 2020.

Baer, M. (2012). Putting Creativity to Work: The Implementation of Creative Ideas in Organizations. Academy of Management Journal, Vol.55, No.5, pp. 1102-1119.

Basrowi. (2011). Kewirausahaan untuk Perguruan Tinggi. Ghalia Indonesia, Bogor. 
Cantaleano, K. R., Rodrigues, G. P., \& Martins, T. S. (2018). The Mediating Effect of Proactive Market Orientation Capability in Entrepreneurial Orientation and Service Innovation. Revista de Administração Mackenzie, Vol.19, No.1, pp. 127.

Choirul, Muhammad. (2017). Aplikasi Game dan Kuliner Jadi Andalan Industri Kreatif Kota Malang, diunduh dari https://malangvoice.com/aplikasi-game-dan-kulinerjadi-andalan-industri-kreatif-kota-malang/ pada tanggal 2 Februari 2020.

Chuckwuemaka, Ofoegbu Wilson and Onuoha, B., C. (2018). Dynamic Capabilities and Competitive Advantage of Fast Foods Restaurants. International Journal of Management Science and Business Administration, Volume 4, Issue 3, Pages 714.

Fang, Niu, Yuli, Zhang and Hongzhi, Xue. (2009). Acquisition of Resources, Formal Organization and Entrepreneurial Orientation of New Ventures. Journal of Chinese Entrepreneurship, Volume 1, Issue 1., pp. 40-52.

Febrianti, Andisa Rizky. (2018). Revolusi Industri 4.0 Bikin Startup Yuk! Diunduh dari https://infodigimarket.com/revolusi-industri-4-0-bikin-startup-yuk/ pada tanggal 6 Februari 2020.

Grant, A. M., \& Berry, J. (2011). The Necessity of Others Is the Mother of Invention: Intrinsic and Prosocial Motivations, Perspective-Taking, and Creativity. Academy of Management Journal, Vol.54, 73-96. https://doi.org/10.5465/AMJ.2011.59215085.

Harvey, S. (2014). Creative Synthesis: Exploring the Process of Extraordinary Group Creativity. Academy of Management Review, 39, pp. 324-343.

Harvey, S., \& Kou, C. (2013). Collective Engagement in Creative Tasks: The Role of Evaluation In The Creative Process In Groups. Administrative Science Quarterly, Vol.58: 346-386.

Hitt, Michael A., Ireland, Duane and Hoskisson, Robert E. (2011). Strategic Management: Competitiveness \& Globalization, 9th Edition, South-Western Cengage Learning, Oklahoma.

Jantunen, A., Puumalainen, K., Saarenketo, S., \& Kyläheiko, K. (2005). Entrepreneurial orientation, dynamic capabilities and international performance. Journal of International Entrepreneurship, Volume 3, Issue 3, Pages: 223-243.

Jati, Yusuf Waluyo. (2017). Ekonomi Kreatif: Aplikasi dan Games Jadi Unggulan di Malang, diunduh dari http://industri.bisnis.com/read/20170706/12/669081/ekonomi-kreatif-aplikasidan-games-jadi-unggulan-di-malang pada tanggal 5 Februari 2020.

Kirkman, B., Li, N. And Porter, C. (2014). Toward a Model of Work Team Altruism. Academy of Management Review, Vol.39, Pp: 541-565.

Kurtmollaiev, Seidali, Per egil Pedersen, and Annita Fjuk Knut Kvale. (2018). Developing Managerial Dynamic Capabilities: A Quasi-Experimental Field Study of the Effects of Design Thinking Training. Academy of Management Learning \& Education, Vol.17, No.2, Pp: 184-202. https://doi.org/10.5465/amle.2016.0187.

Lechner, Christian and Sveinn Vidar Gudmundsson. (2014). Entrepreneurial orientation, firm strategy and small firm performance. International Small Business Journal, Vol. 32, No.1, pp: 36-60. 
Llamas, Alan Cabello. (2015). Human-Centered Innovation Processes the Case of Design Thinking in Nacent and Lager Firms. Ph.D. Dissertation. École Polytechnique Fédérale de Lausanne.

Machfoedz, Mahmud. (2010). Komunikasi Pemasaran Modern. Cetakan Pertama. Cakra Ilmu, Yogyakarta.

MacInerney-May, K. (2012). The Value of Dynamic Capabilities for Strategic Management. Unpublished Doctoral Thesis. Universität zu Köln.

Miller, Danny. (1983). The Correlates of Entrepreneurship in Three Types of Firms. Management Science, Vol.29, Issue 7, Pp: 770-789.

Mohamud, M. and Sarpong, D. (2016), Dynamic Capabilities: Towards an Organizing Framework. Journal of Strategy and Management, Vol. 9 No. 4, Pp: 511-526.

Muller, A. R., Pfarrer, M. D., \& Little, L. M. (2014). A Theory of Collective Empathy in Corporate Philanthropy Decisions. The Academy of Management Review, Vol.39, Issue 1, Pp: 1-21.

Noor, Achmad Rouzni. (2018). Revolusi Industri 4.0 di Era Digital, Indonesia Siap? Diunduh dari https://inet.detik.com/business/d-4033692/revolusi-industri-40-diera-digital-indonesia-siap pada tanggal 5 Februari 2020.

Ogunsiji, A. S. (2010). Entrepreneurial Orientation as a Panacea for the Ebbing Productivity in Nigerian Small and Medium Enterprises: A Theoretical Perspective. International Business Research, Vol. 3, Issue 4, Pp: 192-199.

Plattner, Hasso. (2010). An Introduction to Design Thinking Process Guide, Institute of Design at Stanford. Diunduh pada tanggal 8 Maret 2020 dari https://dschoolold.stanford.edu/sandbox/groups/designresources/wiki/36873/attachments/74b3d ModeGuideBOOTCAMP2010L.pdf.

Poerwanto, Endy. (2017). Pertumbuhan Ekonomi di Malang Dipacu Pariwisata, Diunduh dari https://bisniswisata.co.id/2017-pertumbuhan-ekonomi-di-malangdipacu-pariwisata/ on 3 Februari 2020.

Pratama, Aditya Hadi. (2017). Bagaimana Perkembangan Startup di Indonesia pada tahun 2018 Menurut Para Investor? Diunduh dari https://id.techinasia.com/prediksi-perkembangan-startup-indonesia-2018 pada tanggal 5 Februari 2020.

Rachman, Fadhly Fauzi. (2018). Apa Itu Revolusi Industri 4.0? diunduh dari https://finance.detik.com/industri/d-3952668/apa-itu-revolusi-industri-40 pada tanggal 2 Februari 2020.

Rozaq, Fatkhur. (2018). Peluang dan Tantangan RI Hadapi Revolusi Industri 4.0. Diunduh dari https://www.liputan6.com/bisnis/read/3424837/peluang-dantantangan-ri-hadapi-revolusi-industri-40 pada tanggal 2 Februari 2020.

Samson, Abiodun Tope and Rosli Mahmood. (2014). Integration of Entrepreneurial Orientation and Dynamic Capabilities in Dynamic Environment of Small and Medium Enterprises: A Case of Nigerian Export Firms. International Journal of Economics, Commerce and Management. United Kingdom, Volume II, Issue 10, Pp: 1-11.

Suryana, Taryana \& Sarwono Jonathan. (2007). E-commerce Menggunakan PHP \& $M y S Q L$, Graha Ilmu, Yogyakarta.

Teece, David, Gary Pisano, Gary, and Amy Shuen. (1997). Dynamic Capabilities and Strategic Management. Strategic Management Journal, Vol.18, Issue 7: Pp: 509-533. 
Widianto, Eko. (2016). Kota Kreatif Indonesia dan ASEAN Gelar Konferensi di Malang. diunduh dari https://m.tempo.co/read/news/2016/03/30/090758373/kota-kreatif-indonesiadan-asean-gelar-konferensi-di-malang pada tanggal 5 Februari 2020.

Yusnia, D. A. dan Irma M. (2016). Komite Kreatif, Langkah Cerdas Hadapi MEA. Wawancara Ekslusif. Inspire. Edisi I.

Zehir, Cemal Zehir, Esin Can, and Tugba Karaboga. (2015). Linking entrepreneurial orientation to firm performance: the role of differentiation strategy and innovation performance. 4th International Conference on Leadership, Technology, Innovation and Business Management. Procedia - Social and Behavioral Sciences 210, pp. 358 - 367.

Zulfikar, Raden. (2017). Kota malang Menetapkan Aplikasi \& Games Sebagai Subsektor Unggulan Ekonomi Kreatif. diunduh dari http://www.bekraf.go.id/berita/page/8/kota-malang-menetapkan-aplikasi-gamessebagai-subsektor-unggulan-ekonomi-kreatif pada tanggal 5 Februari 2020. 